\title{
Retained calcified guidewire in the kidney mimicking a renal stone
}

\author{
Silvia Proietti, Luis Rico 지 , Maria Pia Pavia, Guido Giusti
}

Department of Urology, San Raffaele Hospital, Milano, Lombardia, Italy

\section{Correspondence to} Dr Luis Rico;

luisrico_01@hotmail.com

Accepted 25 April 2021
Check for updates

(c) BMJ Publishing Group Limited 2021. No commercial re-use. See rights and permissions. Published by BMJ.

To cite: Proietti S, Rico L, Pavia MP, et al. BMJ Case Rep 2021;14:e242962. doi:10.1136/bcr-2021242962

\section{DESCRIPTION}

A 60-year-old woman presented to the urology clinic with a 3 -week history of right lumbar pain. Two months earlier, she had undergone right flexible ureteroscopy for uric acid renal stones in another hospital. Her medical history was notable for metabolic syndrome, and in particular for severe hyperuricaemia resistant to therapy. Results of a physical examination and complete blood count were normal.

Urinalysis was notable for the persistent presence of leucocytes and bacteria, and a urine culture grew Escherichia coli. Non contrast-enhanced CT of the abdomen revealed a strange finding in the right kidney resembling a kind of calcified skein of thread (figure 1, yellow arrow).

A new endoscopic examination showed a long and tortuous piece of a guidewire completely calcified occupying the right renal pelvis and the lower calyx (figure 2 , video 1 ).

The patient underwent, in the same session, a endoscopic combined intrarenal surgery with complete removal of the wire and residual stone fragments with no postoperative complications.

The stone and the calcification around the wire were sent for chemical analysis that confirmed uric acid composition.

At 1-month follow-up, the patient was stonefree and wire-free. The patient together with the colleague who performed the first surgery and his medical administrator has been informed about the retained foreign body we found in the kidney. Of note, no damage compensation claims arose after that.

In endourology, inadvertent laser injury of baskets or guidewires, or uncontrolled interaction

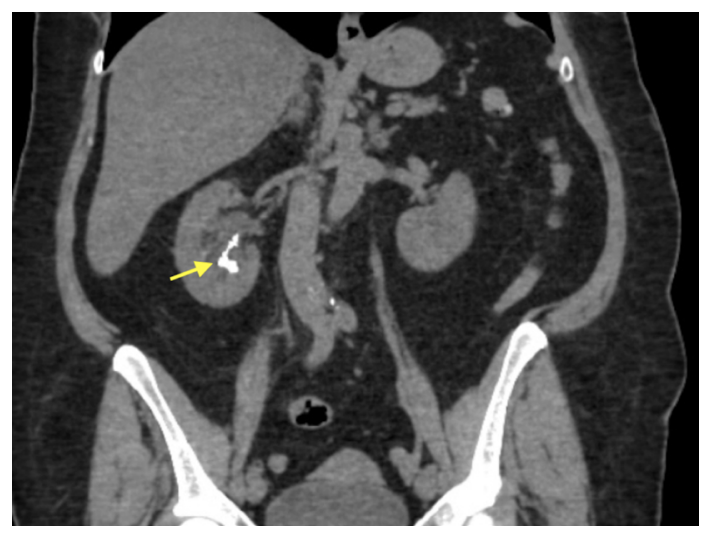

Figure 1 Coronal non-contrast-enhanced image through the abdomen demonstrates long calcified wire in the right renal pelvis and lower calyx (arrowhead).

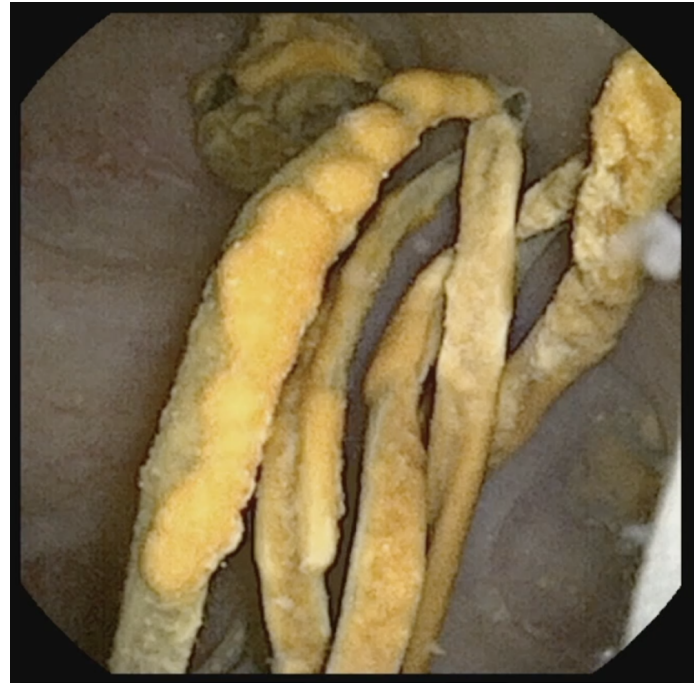

Figure 2 Endoscopic view of the long calcified wire in the right kidney.

between sharp inner lumen of a needle with guidewires and their coating is the most common cause of generation of retained foreign bodies. ${ }^{1}$

Regarding the natural history, the majority of these retained surgical items are shortly noticeable after the intervention, either as prompt discovery or after development of acute symptoms or during the first postoperative follow-up. ${ }^{2}$

Retained renal foreign bodies can act as a reservoir for acute/chronic infection or stone formation or mimic a renal neoplasm; the diagnosis and the extraction can be demanding. ${ }^{3}$

Retained surgical items induce the same concerns of psychosocial and financial burdens on the patient, the involved medical staff and healthcare systems.

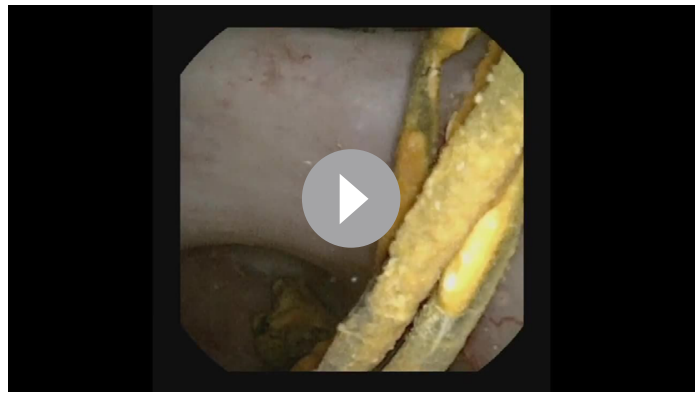

Video 1 Endoscopic examination of the kidney in a 60 -year-old woman with right lumbar pain and previous history of ureteroscopy for renal stones revealed a long and tortuous piece of a guidewire completely calcified occupying the renal cavities. 
Additional procedures for extraction of retained renal foreign bodies or correction of their consequences with related claims require extra financial resources. ${ }^{4}$

Moreover, the involved medical personnel may be subject to administrative and medico-legal actions.

As a matter of fact, legal litigation could be a normal evolution especially when nothing has been told to the patient after the surgery. As such, it is important to be frank with patients when a foreign body is left unintentionally inside them.

\section{Learning points}

- Retained renal foreign bodies can act as a reservoir for acute/chronic infection or stone formation or mimic a renal neoplasm; the diagnosis and the extraction can be demanding

- The surgical aim in the management of retained foreign bodies is to remove them completely and, if possible, in a single stage. In complicated cases, multiple stages can be considered to avoid prolonged surgeries that might imply severe infective complications

- Frankness with patients when a foreign body is left unintentionally inside them is of utmost importance
Twitter Silvia Proietti @sproietti81

Contributors LR collected the images and videos and clinical data for the case report. MPP edited the images and videos. SP, LR, MPP and GG drafted the manuscript.

Funding The authors have not declared a specific grant for this research from any funding agency in the public, commercial or not-for-profit sectors.

Disclaimer Case reports provide a valuable learning resource for the scientific community and can indicate areas of interest for future research. They should not be used in isolation to guide treatment choices or public health policy.

Competing interests None declared.

Patient consent for publication Obtained.

Provenance and peer review Not commissioned; externally peer reviewed.

\section{ORCID iD}

Luis Rico http://orcid.org/0000-0001-9354-3570

\section{REFERENCES}

1 Eisenberg ML, Lee KL, Stoller ML. Endoscopic management of retained renal foreign bodies. Urology 2009;73:1189-94.

2 Gadelkareem RA. Experience of a Tertiary-Level urology center in the clinical urological events of rare and very rare incidence. I. surgical never events: 2 . IntracorporeallyRetained urological surgical items. Curr Urol 2018;11:151-6.

3 Ben Meir D, Lask D, Koren R, et al. Intrarenal foreign body presenting as a solid tumor. Urology 2003;61:1035.

4 Mehtsun WT, Ibrahim AM, Diener-West M, et al. Surgical never events in the United States. Surgery 2013;153:465-72.

Copyright 2021 BMJ Publishing Group. All rights reserved. For permission to reuse any of this content visit

https://www.bmj.com/company/products-services/rights-and-licensing/permissions/

BMJ Case Report Fellows may re-use this article for personal use and teaching without any further permission.

Become a Fellow of BMJ Case Reports today and you can:

- Submit as many cases as you like

- Enjoy fast sympathetic peer review and rapid publication of accepted articles

- Access all the published articles

- Re-use any of the published material for personal use and teaching without further permission

\section{Customer Service}

If you have any further queries about your subscription, please contact our customer services team on +44 (0) 2071111105 or via email at support@bmj.com.

Visit casereports.bmj.com for more articles like this and to become a Fellow 